\author{
EDITED BY \\ RICHARD BROWN
}


(C) 2008 by Blackwell Publishing Ltd

except for editorial material and organization (c) 2008 by Richard Brown

\author{
BLACKIWELL PUBLISHING \\ 350 Main Street, Malden, MA 02148-5020, USA \\ 9600 Garsington Road, Oxford OX4 2DQ, UK \\ 550 Swanston Street, Carlton, Victoria 3053, Australia
}

The right of Richard Brown to be identified as the author of the editorial material in this work has been asserted in accordance with the UK Copyright, Designs, and Patents Act 1988.

All rights reserved. No part of this publication may be reproduced, stored in a retrieval system, or transmitted, in any form or by any means, electronic, mechanical, photocopying, recording, or otherwise, except as permitted by the UK Copyright, Designs, and Patents Act 1988, without the prior permission of the publisher.

Designations used by companies to distinguish their products are often claimed as trademarks. All brand names and product names used in this book are trade names, service marks, trademarks, or registered trademarks of their respective owners. The publisher is not associated with any product or vendor mentioned in this book.

This publication is designed to provide accurate and authoritative information in regard to the subject matter covered. It is sold on the understanding that the publisher is not engaged in rendering professional services. If professional advice or other expert assistance is required, the services of a competent professional should be sought.

First published 2008 by Blackwell Publishing Ltd

$$
12008
$$

Library of Congress Cataloging-in-Publication Data

A companion to James Joyce / edited by Richard Brown.

p. cm.- (Blackwell companions to literature and culture; 52)

Includes bibliographical references and index.

ISBN-13: 978-1-4051-1044-0 (hardcover: alk. paper) 1. Joyce, James, 1882-1941_Criticism and interpretation. I. Brown, Richard, 1954-

$$
\begin{gathered}
\text { PR6019.09Z52715 } 2008 \\
823.912-\mathrm{dc} 22 \\
2007015777
\end{gathered}
$$

A catalogue record for this title is available from the British Library.

$$
\text { Set in } 11 / 13 \text { pt Garamond } 3
$$

by The Running Head Limited, www.therunninghead.com

Printed and bound in Singapore

by Fabulous Printers Pte Ltd

The publisher's policy is to use permanent paper from mills that operate a sustainable forestry policy, and which has been manufactured from pulp processed using acid-free and elementary chlorine-free practices.

Furthermore, the publisher ensures that the text paper and cover board used have met acceptable environmental accreditation standards.

For further information on

Blackwell Publishing, visit our website at

www.blackwellpublishing.com 
9

\title{
James Joyce and German Literature, or Reflections on the Vagaries and Vacancies of Reception Studies
}

\author{
Robert K. Weninger
}

\section{Approaches to Reception and Influence}

Once upon a time and a very good time it was, the greatness of an author was measured by the influence he or she had exerted on later generations of writers. It was the time when the cult of originality ruled supreme and to be influenced was considered tantamount to being a writer of lesser genius, leading even in recent scholarship to such titles as The Burden of the Past (Bate 1971) or The Anxiety of Influence (Bloom 1973). It was the age of nationalism, when great writers were regarded as showcases of the nation's grandeur and their literary masterpieces were taken as proof of its cultural supremacy. Their influence and hence "conquests" were seen as a mirror of the country's intellectual and ideological superiority over other nations and cultures (or, inversely, compensating, as in Germany's case in the second half of the nineteenth century, for its economic delay and as yet unfulfilled imperial aspirations). Goethe in France, Shakespeare in Germany, ${ }^{1}$ Rousseau in England, these are just a sampling of the topics that demonstrated, or were supposed to demonstrate, the eminence and predominance (not just) of one's literary heritage.

Reception studies have come a long way since these heady days of nationalistic favoritism and narrow-mindedness. And in all fairness, comparative literary criticism - in particular following the nationalistic fervor and racial fanaticism of the First and Second World Wars - more often than not struck a humane, anti-nationalist and conciliatory note rather than advocating nationalist or racist zeal. Indeed, the still young history of the discipline suggests that most of its early proponents, people like Hugo Meltzl de Lomnitz at the University of Cluj in Romania, subscribed to a cosmopolitan and polyglot agenda that consciously positioned itself institutionally as a counterbalance to the distinctly national bias of the modern philologies at most European universities of the time. ${ }^{2}$ 
During the heyday of literary theory - the two decades roughly between the mid1960 s and mid-1980s - literary influence and fortune studies went through a number of methodological permutations to become what we today call reception theory, with its various strands of reader-response theory, reception aesthetics and reception history. By the same token, traditional influence and analogy studies have experienced a similar methodological permutation to become subsumed under the more general heading of transtextuality or intertextuality. But regardless of whether we are dealing with fortune or reception, influence or intertextuality, reception studies (in a broad generic sense encompassing all the above aspects) still tend to gravitate towards the great writer, our substantial progress in methodological awareness notwithstanding. "Great writers," those who constitute our canon (at any given moment, one should add warily, since aesthetic canons fluctuate considerably over time), have invariably been the focus of reception studies, partly because they provide the most fertile ground for research, but partly also because literary scholars (and in particular the aspiring doctoral candidate: I myself graduated with an influence/reception study of this kind) need some justification for their endeavors, and what better ticket into the ivory tower - or onto the book market - than the study of the most seminal and widely accepted authors?

James Joyce is just such a "great author." And "James Joyce and German Literature," the subject of this essay, must inevitably result in some form of reception study. But just what form should it take? Within the limited space of one article, it would be impossible to survey in toto Joyce's influence on German literature; that is, the multiple receptions of Joyce by some four or five generations of authors writing in German. Even within this one linguistic tradition (which is divided into German, Austrian, and Swiss German-language writers), Joyce's accumulated Wirkungsgeschichte amounts to a vast and intractable terrain that has been covered piecemeal by numerous scholars in countless essays, books, and published and unpublished MA theses and PhD dissertations. A second option would be to discuss Joyce's reception selectively pars pro toto, his impact on an individual German writer, Alfred Döblin, for instance, or Thomas Mann, or Arno Schmidt. It would pose no difficulty to name forty or more Germanlanguage authors who have been influenced more or less tangibly by Joyce's Ulysses and/or Finnegans Wake - and these are only the cases where a direct influence can be documented (see Weninger 2004). Inversely, and since reception history by definition must have at least two vectors, one pointing forward from Joyce, the other, also pointing forward, but to Joyce, one could ask how Joyce was influenced by German writers, Johann Wolfgang von Goethe (1749-1832) for example, whose Wilhelm Meister figures prominently at the beginning of "Scylla and Charybdis," the library chapter of Ulysses, where we read, "And we have, have we not, those priceless pages of Wilhelm Meister. A great poet on a great brother poet" (U 9 2-3). Or the revered Gerhart Hauptmann (1862-1946), two of whose plays the early Joyce translated into English; at the close of his 1901 essay "The Day of the Rabblement," Joyce, not yet 20, proclaims rather self-conceitedly, but nonetheless prophetically, 
Elsewhere there are men who are worthy to carry on the tradition of the old master who is dying in Christiania [i.e. Henrik Ibsen]. He has already found his successor in the writer of Michael Kramer [i.e. Gerhart Hauptmann], and the third minister will not be wanting when his hour comes [i.e. James Joyce]. Even now that hour may be standing by the door (OCPW 52).

Or Friedrich Nietzsche (1844-1900), the "neatschknee" of Finnegans Wake ( FW 346 2), whose Dionysian concept of drama features as early as 1900 in Joyce's formative essay "Drama and Life" (OCPW 22-9), written at the young age of 18 , and whose Übermensch appears as late as 1939 in Finnegans Wake as "Overman" (FW 302 left).

In short, there are many trajectories this essay could take. But rather than rehearse what has already been said and done - and what not has already been said and done in the interminably vast tracts of Joyce scholarship, rivaled only by the even more limitless scholarship on the works of William Shakespeare? - I hope to illuminate a few of the remaining white patches that define the geo-literary map of the Joyce-German cosmos; and in so doing I hope also to shed light on some of the vagaries and vacancies of reception studies. As the major reception studies series The Reception of British and Irish Authors in Europe - with volumes among others on Virginia Woolf (2002), Ossian (2004), Laurence Sterne (2004), Walter Pater (2004), James Joyce (2004), and Byron (2005) - illustrates, the "old" concept of influence remains as indispensable an analytical tool of reception studies as ever, its overlap and recent rivalry with the term intertextuality notwithstanding. In terms of influence, reception studies always possess two vectors: influence on an author by others and influence by an author on others. The old-style French school of comparative literature traditionally premised any such influence study on a so-called rapport de fait, a demonstrable factual link between two authors and their works. Such factual links are typically made manifest by an explicit mention of a name or title of an earlier author either in a literary work by a later author or in her or his letters, diaries, or interviews; a rapport de fait can also take the form of a translation or adaptation of an earlier author's work by a later author. ${ }^{3}$ As tangible as they may be, limiting oneself to the study of rapports de fait can be problematic, however; on occasion they hold out more promise of results than an actual comparative reading will yield, and they tend to occlude or marginalize the less palpable kind of intertextual link, for example an analogy or affinity between literary contemporaries, which in their own right can constitute a third vector of influence studies, even if an actual influence has not taken place.

The reception history of Joyce in German literature is full of such occlusions in part because influence often occurs negatively rather than positively, an author feeling pressured to demonstrate precisely that he was not influenced by his predecessor - influence again being taken as an unwelcome sign or token of epigonality (viz. Harold Bloom's Anxiety of Influence, where wilfully swerving away from one's precursor plays such a crucial part in the psychological formation and artistic development of "strong, authentic authors" [Bloom 1973: 30]) - in part because an influence like that of Joyce is often disseminated indirectly via intermediaries. Thus Breon Mitchell correctly pointed out in his important study James Joyce and the German Novel 1922-1933 that "by the 
mid-thirties ... it would not be surprising to see a German writer mix inner monologue and third-person narrative in his novel without ever having read a word of Joyce - provided he had read Berlin Alexanderplatz or Perrudja," the former by Alfred Döblin. the latter by Hans Henny Jahnn, both of whom substantially revised their novels-inprogress under the immediate spell of the freshly published German translation of Ulysses in 1927 (Mitchell 1976: 177). What I would like to spotlight in the following, therefore, are examples of each of these three vectors, examples that, on the one hand, have not yet been sufficiently explored by Joyce scholars but which, on the other hand, provide fresh insight into the complex nature and sometimes fluid dynamics of reception studies.

\section{Gustav Freytag as Influence}

The first of these lesser-explored German trajectories is the mid-nineteenth century novel Soll und Haben by the novelist, playwright, and essayist Gustav Freytag (181695). Freytag's novel is the only foreign-language publication in Leopold Bloom's small but select personal library of "inverted volumes improperly arranged" ( $U 17$ 1358), as if his eclectic collection of some 23 "scintillating titles" ( $U 17$ 1359) - ranging from Thom's Dublin Directory through The Beauties of Killarney (author anonymous), William O'Brien's When We Were Boys, and Robert Ball's The Story of the Heavens and The Philosopby of the Talmud, to Hozier's History of the Russo-Turkish War - could ever be properly arranged. The sparse "catalogue" entry for Freytag s novel reads: "Soll und Haben by Gustav Freytag (black boards, Gothic characters, cigarette coupon bookmark at p. 24)" ( $U 17$ 1383-4). Neither the book nor its author are ever mentioned again in Ulysses, or anywhere else in Joyce's work for that matter. The appearance of Freytag's novel in Ulysses poses a veritable enigma for interpreters, as Erwin Steinberg and Christian Hallstein have only very recently pointed out, not just because it is a book in German but also because it exhibits a strong anti-Semitic bias, which explains why the novel later found itself ostracized, at least in Germany, as part of the prehistory of German Nazism (Steinberg and Hallstein 2003). But what is a book like this doing here, they ask, occupying valuable space on Leopold Bloom's two bookshelves? Does Bloom know German? Can he read Freytag in the original? Well, as a matter of fact, we cannot be quite sure: after all, earlier that day in the "Hades" chapter, Bloom had mused about his pregnant wife Molly and prematurely deceased son Rudy: "Got big then," he recollects. "Had to refuse the Greystones concert. My son inside her. I could have helped him on in life. I could. Make him independent. Learn German too" (U 6 82-4). If it is unclear here whether Bloom was intending to teach himself or his son German, we do know that Rudolph Virag, Bloom's father, was born a Hungarian Jew and lived, among other places, in Vienna. And of course, during the second half of the nineteenth century, many Hungarians, as Austro-Hungarians, would have spoken German more or less fluently. Indeed, among the "fractions of phrases" Bloom remembers his father using are some German words, namely "das Herz ... Gott ... dein" 
(U 17 1885-6). ${ }^{4}$ However, even if he did know German, which is the more likely scenario, the lines suggest that Bloom never progressed far enough into the novel to learn of its anti-Semitic tendency, for is this not the conclusion we are to draw from the bookmark placed between pages 24 and 25? Now, I do not know which edition of Freytag's Soll und Haben Joyce is describing here; the narrator's bibliographical referencing skills are clearly not up to scratch. But there is something peculiar at play here, one of the many vagaries of reception that I refer to in my title and that Steinberg and Hallstein refer to as a textual "silence." I have before me the one-volume 1858 edition of the popular and well-circulated translation of Freytag's novel into English, published under the title Debit and Credit and prefaced by a Chevalier Bunsen. This preface was intended for an English audience and is not contained in any German version that I know. Page 24 of this edition marks the end of Bunsen's preface and Freytag's "Dedications," with Chapter One beginning on page 25. Hence, if Bloom had possessed this English edition instead of a German one, he would not even have read the first page of the novel. So what? You might think with Bloom: "Coincidence" (U 11713 ), and leave it at that. But there is more to this than meets the eye. Let us assume for a moment that Joyce knew the English translation (or even that Bloom might have owned this English version rather than the German one), what else might be noteworthy? For one thing, there is Bunsen's astonishing remark (for those like T. S. Eliot who immediately recognized the importance of Joyce's ingenious idea to construct myth as a "continuous parallel between contemporaneity and antiquity" and as "a way of controlling, of ordering, of giving a shape and a significance to the immense panorama of futility and anarchy which is contemporary history" [Eliot 1975, 177]) that "Every romance is intended, or ought to be, a new Iliad or Odyssey" (Bunsen in Freytag 1858: viii). Moreover, if we wonder where and why Bloom ever obtained a copy of this book in a language that he may not understand, the answer could lie in Bunsen's opening comment:

To form a just conception of the hold the work has taken of the hearts of men in the educated middle rank, it needs but to be told that hundreds of fathers belonging to the higher industrious classes have presented this novel to their sons at the outset of their career [... . B (Bunsen in Freytag 1858: vii).

Are we to assume, then, that Rudolph Bloom, né Virag, Leopold Bloom's father, who was probably conversant in German, presented Freytag's novel to his son and that Leopold Bloom planned on presenting it in turn to his son Rudy as a kind of male family heirloom? But as if that were not enough, toward the end of his preface Chevalier Bunsen draws a parallel between the Poles in their relationship with the Prussians in the German-Polish borderlands, where much of the novel plays, and the Catholic Irish in their relationship with Irish Protestants. The relevant passages read (and we need to substitute Poles for Catholic Irish and Germans for Protestants):

The two national elements may be thus generally characterized: The Prusso-German element is Protestant; the Polish element is Catholic. Possessing equal rights, the former 
is continually pressing onward with irresistible force, as in Ireland, in virtue of the principles of industry and frugality by which it is animated. . . Forming, as they once did, with the exception of a few German settlements, the entire population of the province, the Poles have become, in the course of the last century, and especially since the removal of restrictions on the sale of land, less numerous year by year. In Posen proper they constitute, numerically, perhaps the half of the population; but in point of prosperity and mental culture their influence is scarcely as one fourth of the whole. On the other hand, in some districts, as, for instance, in Gnesen, the Polish influence predominates in the towns, and reigns undisputed in the country. The middle class is exclusively German or Jewish; where these elements are lacking, there is none (xviii-xix).

As regards Freytag's portrayal of Jews, Bunsen notes somewhat euphemistically:

It is a pretty general feeling in Germany that Freytag has not dealt altogether impartially with this class, by failing to introduce in contrast to the abandoned men whom he selects for exhibition a single honest, upright Jew, a character not wanting among that remarkable people (xviii).

Ironically, in Ulysses Joyce reverses this numerical imbalance: his novel parades precisely the "single honest upright Jew" who in Freytag's novel is so conspicuously lacking. However, from the textual evidence alone there is no way that we can deduce conclusively whether these intertextual connections represent mere "reminiscences of coincidences, truth stranger than fiction" ( $U$ 17 323), or whether they have been planted by design. All we can say is, knowing how scrupulously Joyce attended to every detail of his novel, that there must be some reason, some particular logic why Bloom is made to own a German edition of Freytag's mid-nineteenth-century anti-Semitic novel even if the precise intention on Joyce's part remains occluded, as Steinberg and Hallstein rightly conclude. Ulysses remains "silent," they maintain, "about the meaning of that uniqueness or the reason the Blooms would have such a volume on their bookshelf" (Steinberg and Hallstein 2003: 547).

Ultimately, the focus of Steinberg and Hallstein's article is the stratagems critics employ when they attempt to recover authorial intentions from insufficient textual evidence - something we do more often than we think and without realizing it. They use the example of Gustav Freytag's novel to illustrate how critics often stake out authorial intention where in actual fact what is created is only the critic's "personal fiction" of what a text means. ${ }^{5}$ Influences, too, are like this, "personal fictions" that arise from our linking of literary personages (Goethe and Joyce, Joyce and Arno Schmidt) or works of world literature (Wilhelm Meister and Ulysses, Finnegans Wake and Zettels Traum). Such linkings enable us to construct stories of genealogy and interdependence, give and take, debit and credit. I do not want to depreciate the value of these stories: we need them to make, and to make sense of, literary history. But what really goes on in authors' minds will of course remain forever shrouded, as my next example will show. 


\section{The Potential Connection with Heinrich Böll}

A similar void or vacancy surrounds the relationship between Joyce's works and the postwar German writer, political essayist, and translator Heinrich Böll. Critics agree that the Nobel Prize-winner of 1972 underwent a period of transition during the early 1950s. With novels like Und sagte kein einziges Wort (1953) and Haus obne Hiiter (1954) he successfully abandoned his Trïmmerliteratur signature style which was permeated by the experience of war, death, and physical and spiritual deprivation. New motifs and more contemporary settings emerged as Böll increasingly lashed out both in his fiction and in his essays against the moral hypocrisy and inhuman materialism of the Phoenix-like economic resurgence of Wirtschaftsuunder Germany. At the same time, a gradual but tangible shift away from the largely unsophisticated realism of Böll's literary beginnings was taking shape, leading him to the much more elaborate forms and sophisticated configurations of such books as Billard um balbzehn, his landmark novel of 1959, which exhibits extensive symbolical cross-referencing, or Gruppenbild mit Dame (1971), with its unprecedented complexity of character portrayal.

This shift or new departure may well be attributable at least in part to Böll's getting to know the work of James Joyce around 1954 when he began traveling to Ireland (see Weninger 1998). Indeed, the earliest mentionings of Joyce in Böll's work occur in his popular travelogue Das irische Tagebuch, which was published in 1957. It is worth noting, however, that none of these comments is formulated in a way that would presuppose more than a superficial knowledge of Joyce's writings. And later, too, we find only the occasional allusion to or mention of the Irish writer in Böll's literary work. Nor does Joyce or his œuvre figure prominently in Böll's countless essays and interviews on writers and writing. Even in the short article "Über den Roman" (On the Novel) of 1960, which deals specifically with the modern novel and would provide a natural opportunity to acknowledge his indebtedness to Joyce, Böll refers neither to A Portrait of the Artist as a Young Man nor to Ulysses, not to mention Finnegans Wake. This fact in itself is rather astonishing, considering Böll's genuine interest in Irish literature (he goes on in the 1960 s and 70 s to translate, together with his wife, the works of numerous Irish writers into German, among them Brendan Behan, John Millington Synge, and George Bernard Shaw). Tellingly maybe, the narrator of Böll's novel Gruppenbild mit Dame deems Leni Gruyten, the book's central character, only a "potential" reader of Joyce. "To be sure," he speculates, "- if frivolous books of this sort had ever come within her reach as potential reading matter -, she would have become a Proustreader rather than a reader of Joyce." "It is quite possible that Böll, like his fictional narrator, considered Joyce's work far too frivolous to merit scrutiny. For all we know, Böll may actually never have skipped through more than a couple of pages of his work (which, as we know, often suffices to get a rough but nevertheless first-hand impression of Joyce's techniques). So despite the occasional mention, despite that isolated rapport de fait, Joyce leads at best an eclipsed life in Böll's literary household.

However, as elusive as the link between the Irish and the Germans writer might 
be, it seems ironical that, at least since the appearance of Billard um balbzehn in 1959. critics have not ceased to tie Böll's turning to experimental techniques to the influence of James Joyce. But any attempt to pinpoint the formal correspondences - most frequently cited among them are Böll's increased use of interior monologue and montage techniques after the mid-1950s - seems doomed if only because these echoes or parallelisms can be attributed as easily, if not more convincingly, to influences other than that of Joyce. The mediators were more likely Alfred Döblin or William Faulkner, writers with whose works Böll was demonstrably familiar. Whatever the case, Böll himself cautions us to beware of the pitfalls of influence studies; in an interview of 1971 he remarks acutely from a writer's point of view:

One does not consciously copy a style, at least practically, but rather one seeks one's own expression within the tensions of the author one currently considers exemplary. The process is fascinating, but I don't believe it reveals anything about the quality of an author to know who has influenced him. Sometimes I am inspired by some stupid movie I have seen and in some corner of it there's an idea that I find attractive but that is kitsch. It can become more important as an entry point than reading the complete works of, say, Camus, who I think is very interesting and who was immensely important for me.

This comment is useful in that it reminds us to heed Claudio Guillén's cautionary words when he observed that "an influence need not assume the recognizable form of a parallelism, just as every parallelism does not proceed from an influence" (Guillén 1971:35).

Because Joyce's formal innovations in Ulysses or Finnegans Wake, his two most celebrated works, are so uniquely distinctive, any similarity or parallelism is quickly noted and equally quickly attributed to his influence even when other contenders present themselves. What this focus on Ulysses or Finnegans Wake frequently makes us overlook, however, is that there are other avenues through which Joyce's works might have impacted on a writer like Heinrich Böll. (Not to mention the fact that, at least until the mid-1950s, Böll would have possessed neither the time nor the energy to devote himself to any sustained reading of Joyce's rather obscure and intractable masterpieces; following his return from the front lines of the Second World War, the former Webrmacht soldier was preoccupied with a very different kind of battle, namely one for his and his family's very survival in war-torn Germany.) In the 1950s, when Böll seems to have first encountered Joyce's writings, he was primarily preoccupied with short prose forms rather than with the bulkier genre of the novel; hence it is not unlikely that Böll encountered the Joyce of Dubliners before discovering the Joyce of Ulysses. We can infer as much from a remark made during an interview given in the mid-1970s: "Since I still believe," he tells his interlocutors Nicolas Born and Jürgen Manthey, "that I am by nature a short-story writer [ein Kurzgeschichtenschreiber], I have taken most interest in those colleagues of mine who are writers of short stories" (Böll 1977: 50). If we take this comment seriously and focus our attention less on formal similarities and parallelisms between, say, Billard um halbzehn and Ulysses and more on theme, tone, narrative pitch, and mood, we might notice that a number of Böll's shorter prose texts, and in 
particular those written in the mid-1950s when he started traveling to Ireland, exhibit tangible convergences with Joyce's own short stories in Dubliners.

As I have argued elsewhere, Böll's Das irische Tagebuch as well as his remarkable short story "Im Tal der donnernden Hufe" (In the Valley of Thundering Hoofs), both of which were published in 1957 , carry such eminently Joycean overtones. While the contentual parallels are less palpable than the affinities in tone and mood, the similarities - conjoined with the fact that we can assume Böll's familiarity with Joyce's Dubliners - can justify reading these stories against the interpretative backdrop of such Joycean meta-concepts as "paralysis" and "gnomon," bringing to the fore their more sinister hues. Not surprisingly, both authors' short narratives have been mistaken for simple, uncomplicated, and unmediated depictions of everyday life. In the case of Joyce's Dubliners, critics have long since become aware of the existential abyss that lurks beneath their seemingly straightforward naturalistic surface and have corrected their readings accordingly, establishing in the process what Bernard Benstock has called "gnomonic criticism" (Benstock 1976: 428). In Böll's case, it seems high time to take a fresh look at, and to re-evaluate, the purportedly "uncritical" and socially less involved tales of the middle period of his career, including Das irische Tagebuch, and to attend "gnomonically" to the existential silences and veiled psychological meanings that lie behind and beneath the seemingly uncomplicated surfaces of these narratives.

\section{Ostensible Non-connection with Rilke}

What Böll's remarks also point to is that no serious writer likes to be considered derivative. The naming game of influence remains as intimidating, injurious, and damaging to authors as ever - even in our current condition of postmodernity in which what was once embarrassing and stigmatizing influence is oftentimes too easily elevated to, or conflated with, consciously cunning citationism. Nevertheless, and fortunately, since the advent of intertextuality around the 1960s, attitudes have changed significantly and this kind of rigid exclusionary practice and stigmatization of influence has by and large become obsolete in literary theory and criticism, although maybe less so in terms of Literaturkritik, i.e. book reviewers' attitudes towards originality and epigonality. While intertextual relationships where no rapports de fait are found to exist may indeed be less tangible, they are frequently no less illuminating and worthwhile pursuing, especially when they obtain between works conceived or written at about the same time, documenting some form of common Zeitgeist, or spirit of the age. An often cited example is Joyce writing his revolutionary Ulysses in Zurich during the heyday of the equally revolutionary and anti-institutional art movement Dadaism all the while Lenin lived around the corner preparing his Bolshevist version of a modern political revolution. The fact that no literary historian dared to venture where tangible rapports de fait were felt to be lacking allowed the playwright Tom Stoppard to capitalize all the more liberally on this historical coincidence. In his 1975 play Travesties, 
a wonderfully farcical drama, Stoppard has James Joyce, Tristan Tzara, and Lenin, these three very different revolutionaries, all of them exiles on foreign soil and operating within a foreign culture and language, meet and interact, ironically without ever really taking notice of one another.

Another such relationship, one from which quite substantial correlational insight can be extracted, as we shall see, is the connection, or ostensible non-connection, between Joyce and the Prague-born German-language writer Rainer Maria Rilke (1875-1926). ${ }^{8}$ However, in order to investigate this - as yet - unexplored vacancy of reception in more detail we need to backtrack for a moment to Joyce's biography. On December 1, 1902, a 20-year-old James Joyce leaves Dublin for Paris. It is his first trip abroad. Like many a young student separated from home for the first time, he initially cannot bear to stay longer than three weeks, heading home to spend Christmas with his parents on December 22. Ellmann records: "The prospect of going home, even if he was seasick on the way, was delightful" ( $J J 115$ ). Joyce returns to the French capital on January 17, 1903, where he remains until April 11, when his mother's failing health forces him once again to return home. "By the third week in February," Ellmann reports, "hunger had become Joyce's principal theme in his letters home. Scarcity was succeeded by famine, famine, after a brief splurge, by scarcity and famine again, diminuendos of stomach twinges followed by crescendos of starvation" ( $J$ 122). Living in the Hotel Corneille, 5 rue Corneille, the aspiring young artist meets with little success; his articles, with which he was hoping to improve his dire financial situation, are either not accepted or their publication is delayed. Already in December he had given up on his planned medical studies, so he now immerses himself in literature and philosophy in the Bibliothèque Nationale and the Bibliothèque Sainte-Geneviève instead - he is "up to his eyes in Aristotle's psychology," Joyce writes to his brother Stanislaus on February 8 . With his regular nourishment being more intellectual than alimentary - "My next meal will be at $11 \mathrm{a} . \mathrm{m}$. tomorrow (Monday): my last meal was 7 pm last (Saturday) night. So I have another fast of 40 hours" (LII 28, 34, 35), he admits to his father around March 8 - his health soon begins to deteriorate. "Damnably cold here," he complains the next day to Stannie, maybe summarizing not only the weather but also the social and intellectual climate he encountered in Paris.

At about the same time and a couple of streets further down, in the rue Toullier, another aspiring young writer had taken up residence in the Latin Quarter. He too had come from afar, from Denmark, originally of noble stock, but now, not unlike Joyce, impoverished and hungry. This young artist has no acquaintances worth mentioning; he traverses the city, observing, reflecting, taking notes:

How ridiculous. I sit here in my little room, I [ . . . who am twenty-eight years old and completely unknown. I sit here and am nothing. And yet this nothing begins to think and thinks, five flights up, on a gray Paris afternoon, these thoughts: Is it possible, it thinks, that we have not yet seen, known, or said anything real and important? Is it possible that we have had thousands of years to look, meditate, and record, and that we have let these thousands of years slip away like a recess at school ... (Rilke 1990: 22). 
Lenin, operatout ever

"I have taken action against fear," he notes elsewhere. "I sat up all night and wrote" (Rilke 1990: 16-17). His writing is his only elixir, and it is through it that he is learning to read the reality of the city around him:

I think I should begin to do some work, now that I am learning to see. I am twentyeight years old, and I have done practically nothing. To sum it up: I have written a study of Carpaccio, which is bad; a play entitled "Marriage," which tries to demonstrate a false thesis by equivocal means; and some poems (Rilke 1990: 19).

Are we not immediately reminded of James Joyce, who at this point in time has written a mere handful of essays on such subjects as Ibsen, Mangan, and "Drama and Life"; a drama entitled A Brilliant Career (written and destroyed in 1901, maybe because it too attempted "to demonstrate a false thesis by equivocal means"?); and a smattering of largely mediocre verse? In Paris in early 1903 he seems also to have been writing a comedy. But this, too, like A Brilliant Career, has not survived. And how frustrated must Joyce have been to receive the following lines from William Butler Yeats:

I think the poem that you have sent me has a charming rhythm in the second stanza, but I think it is not one of the best of your lyrics as a whole. I think that the thought is a little thin. Perhaps I will make you angry when I say that it is the poetry of a young man who is practising his instrument, taking pleasure in the mere handling of the stops (JJ 114).

Joyce's counterpart in the above example, the 28 -year-old Danish artist, is, as some may already suspect, not a real author. Rather, he is the fictional character Malte Laurids Brigge, created by Rilke at the very moment when Joyce was composing A Portrait of the Artist as a Young Man, namely the years 1903 to 1910.' We know from Rilke's biography that Malte Laurids Brigge's experiences in Paris are modeled on the author's own experiences in the French capital. Rilke was about to turn 27 when he arrived there on August 28, 1902, only three months before Joyce. Nor did Rilke stay long, like his Irish counterpart. Rilke found Paris too unwelcoming and oppressive. He wrote to his close friend and occasional companion Lou Andreas-Salomé (better known to many in the Anglo-Saxon world for her close ties with the philosopher Friedrich Nietzsche) on July 18, 1903:

I must tell you, dear Lou, that Paris was an experience for me not unlike the Military School that I attended; at the time I was seized by a great anxious amazement; now again I was overpowered, as if in total confusion, by a dread of everything that is called life. ${ }^{10}$

While Rilke was already an established writer in the German-speaking world at this point in time - he had published a number of respectable volumes of poetry, in particular in 1902 Das Buch der Bilder - he had little international renown; his most famous volumes of poems were still to come, the Nene Gedichte of 1907 (Volume 1) and 1908 (Volume 2, Neue Gedichte anderer Teil), his Sonette an Orpheus, published in 1923, and his supreme achievement, the Duineser Elegien, also published in 1923. And, of course, Rilke was not yet the author of The Notebooks of Malte Laurids Brigge, the 1910 novel 
that was to become one of the earliest showpieces of German modernism and one of its defining moments. All the while Joyce was still an inconmue. Understandably, the two men - both of whom would come to rank among the greatest writers in their respective literary traditions - never met, and why should they have?

And yet, even beyond the mere biographical coincidence of their living in more or less the same location at more or less the same moment in time, there are links between these two literary heavyweights that seem to take us beyond the realm of mere literary parallelism. The following quote sets the stage, I believe, for one of the most remarkable accidental - that is, non-causal - intertextual linkages in early twentieth-century modernism: "Ah, but poems amount to so little," Malte speculates,

when you write them too early in your life. You ought to wait and gather sense and sweetness for a whole lifetime, and a long one if possible, and then, at the very end, you might perhaps be able to write ten good lines. For poems are not, as people think, simply emotions (one has emotions early enough) - they are experiences. For the sake of a single poem, you must see many cities, many people and Things, you must understand animals, must feel how birds fly, and know the gesture which small flowers make when they open in the morning. You must be able to think back to streets in unknown neighborhoods, to unexpected encounters, and to partings you had long seen coming; [. . . ] But you must also have been beside the dying, must have sat beside the dead in the room with the open window... (Rilke 1990: 19-20).

While Rilke wrote more than ten good lines in his lifetime, it is amazing to note in hindsight just how clairvoyantly he is predicting in 1910 his own future and the culmination point of his career in the early 1920s. Yet, in some ways, Malte is also describing James Joyce's literary trajectory (setting aside for the moment the generical argument about poetry). But more importantly, Malte is formulating a literary programe that comes close to one of Joyce's central aesthetic concerns during those early years of the twentieth century. Rilke's translator here has highlighted the issue for the English-language reader by giving the word "thing" (German Ding) in upper case as "Thing." Between Rilke's first sojourn in Paris in 1902-3, with his formative encounter with the sculptor Rodin, and the completion and publication of The Notebooks of Malte Laurids Brigge in 1910 lie the years when Rilke composed his "New Poems." In these, Rilke creates and gives form, in poetic language rather than critical discourse, to a uniquely modern theory of the apperception of a "Thing" (Ding). These poems subsequently became known in German as Rilke's Dinggedichte ("Thing" poems) and they represent one of German literature's pre-eminent contributions to the history of twentieth-century poetry. Rilke's poetological program was less to describe things in poetry than to make them, "to create things" (Dinge zu machen), he writes to Lou Andreas-Salomé, "not solid written things - [but] realities that spring from my craft." ${ }^{11}$ Through poetry, things both become reality and create reality. As one critic noted, Rilke's Dinggedichte aim to craft, as do Rodin's sculptures that served as Rilke's model, "static situations and visions of situations, in which a slice of our emotional life presents itself, without clamor and without a sigh, like a thing.,"12 
le of its the two respec-

more or setween literary emarkcentury
This is the context also for Malte Laurids Brigge's persistent attempt to formulate an aesthetics that would carry his poetry beyond its current impasse. In one of the earliest sections of Malte's notebooks, Rilke has him reflect, "I am learning to see. I don't know why it is, but everything enters me more deeply and doesn't stop where it once used to. I have an interior that I never knew of' (Rilke 1990: 5). Shortly thereafter he notes,

Have I said it before? I am learning to see. Yes, I am beginning. It's still going badly. But I intend to make the most of my time. For example, it never occurred to me before how many faces there are. There are multitudes of people, but there are many more faces, because each person has several of them ... (Rilke 1990: 6).

This new sensation of seeing things for the first time, and of seeing them more clearly and intensely than ever before, is encapsulated most vividly in the following passage, a passage, however, that belongs not to the final version of the novel but to an earlier draft:

These clarities [Klarbeiten] are so peculiar; one never expects them. They hit you when you are getting into a bus, or when you are sitting in a restaurant with the menu in your hand, while the waitress is standing close by - : suddenly you are unable to see what is printed on the menu, you can no longer imagine eating: because a clarity has hit you, just now, while you were looking at the menu, reading the names of dishes, sauces or vegetables, just at that moment it hit you [ . . . today this kind of clarity came to me on the Boulevard des Capucines when I was crossing the wet road weaving through the heavy traffic trying to get to the Rue Richelieu, there, right in the middle, it lit up within me and for a second was so bright that I could see not just a very distant memory but also some rather peculiar relationships which connected an early and seemingly irrelevant event to my life (Rilke 1997: 218-19; my translation).

Composed during a visit to Rome during the winter of 1903-4, this posthumously published early draft of the novel's first pages pre-dates Proust's Du Côté de chez Swann, the first volume of $A$ la Recherche du temps perdu, by some ten years and was composed roughly at the same time (namely February 1904, as far as we know) that James Joyce was beginning to write Stephen Hero, the first chapter of which was drafted in January and February 1904.

In other words, at the very moment when Joyce is collecting epiphanies and formulating a theory of the epiphany in his Paris notebooks in early 1903, Rilke has his protagonist Malte Laurids Brigge draft a similar aesthetics in his Paris notebook. And just when Joyce is incorporating his theory of the epiphany into Chapter 25 of Stephen Hero around the second half of 1905 , Rilke has just drafted the first pages of a novel, to be entitled The Notebooks of Malte Laurids Brigge, that contain a comparable theory of the "sudden spiritual manifestation" of objects or situations.

Stephen's (and hence of course Joyce's) definition of epiphany runs as follows:

he meant a sudden spiritual manifestation, whether in the vulgarity of speech or of gesture or in a memorable phase of the mind itself. [. . . . First we recognize that the object is one integral thing, then we recognize that it is an organized composite structure, a thing 
in fact: finally, when the relation of the parts is exquisite, when the parts are adjusted to the special point, we recognize that it is that thing which it is. Its soul, its whatness, leaps to us from the vestment of its appearance. The soul of the commonest object, the structure of which is so adjusted, seems to us radiant. The object achieves its epiphany (SH 216 and 218).

The narrator continues:

He believed that it was for the man of letters to record these epiphanies with extreme care, seeing that they themselves are the most delicate and evanescent of moments. He told Cranly that the clock of the Ballast Office was capable of an epiphany (SH 216).

Not only is Malte Laurids Brigge replete with such epiphanies, many of which might have been lifted directly out of Joyce's own collection of such epiphanic "visions," but most of Rilke's Dinggedichte might rightly be characterized as poetic equivalents of such Ballast Office manifestations of "whatness." But, as Morris Beja notes in the most thorough study of Joyce's and other modernists' use of epiphanies to date, Joyce conceives them as "produced much less frequently by concrete objects than by events, people, snatches of talk, gestures, dreams, phases of the mind" (Beja 1971: 80). ${ }^{13}$ Throughout much of his novel Rilke, too, seems to focus epiphanically less on objects than on people, memories (in particular of Malte's childhood), death and illness, ghosts and masks, or the sites and sights of Paris, its houses, streets, shops, hospitals, and institutions; at times we even encounter epiphanies of reading, for instance Malte's comments on Baudelaire's poem "Une Charogne" (72) or his meditations on the "reading" of such medieval tapestries as La Dame à la licorne (127-31). Sections xi and xiii of Malte Laurids Brigge provide particularly instructive examples of how Rilke weaves such epiphanic tableaux or short poems in prose that revolve around objects, persons, and everyday events into the tapestry of his novel:

xi: Today we had a beautiful autumn morning. I walked through the Tuileries. Everything that lay toward the East, before the sun, dazzled; was hung with mist as if with a gray curtain of light. Gray in the gray, the statues sunned themselves in the not yet unveiled garden. Single flowers in the long parterres stood up to say: Red, with a frightened voice. Then a very tall, thin man came around the corner from the Champs-Elysées. He was carrying a crutch, but it was no longer thrust into his shoulder-pit: he was holding it out in front of him, lightly, and from time to time he hit the ground with it, firmly and loudly, as if it were a herald's staff. He couldn't repress a joyful smile, and smiled, past everything, at the sun, the trees. His step was as bashful as a child's, but extraordinarily light, filled with memories of an earlier walking (Rilke 1990: 17-18).

xiii: In the street below there is the following group: a small wheelbarrow, pushed by a woman; lengthwise across the front of it, a barrel-organ. Behind that, a small crib in which a baby is standing on firm legs, chuckling with delight under its bonnet, not wanting to be sat down. From time to time the woman turns the organ handle. Then the baby immediately stands up again, stamping in its crib, and a little girl in a green Sunday dress dances and beats a tambourine lifted up toward the windows (Rilke 1990: 18-19). 
adjusted hatness, ject, the piphany

xtreme nts. He 16).

ich might ions," but valents of the most oyce conby events $71: 80)^{13}$ on objects d illness, os, hospi$r$ instance ations on ections xi low Rilke d objects,
Similarly, in his Dinggedichte Rilke focuses as often on people and events as on objects. "Pont du Carrousel" for example, an early (and still rather immature) prototype composed in 1902 when Joyce was in Paris for the first time, revolves around the poet "seeing" a blind man, envisioning his essence:

Pont du Carrousel

That blind man standing by the parapet,

Gray as some nameless empire's boundary stone,

He is perhaps that thing-in-itself-alone

To which Eternity's image Time is set,

The silent centre of the starry ways;

For all around him strives and struts and strays,

Right, with inflexible deliberation;

Flag over many wavering faiths unfurled;

The dusky entrance to the underworld

Among a superficial generation.

(Rilke 1939: 18) ${ }^{14}$

For comparison's sake, here are two of Joyce's epiphanies, one as it occurs in A Portrait of the Artist as a Young Man, the second as it appears in the author's notebooks:

The quick light shower had drawn off, tarrying in clusters of diamonds among the shrubs of the quadrangle where an exhalation was breathed forth by the blackened earth. Their trim boots prattled as they stood on the steps of the colonnade, talking quietly and gaily, glancing at the clouds, holding their umbrellas at cunning angles against the few last raindrops, closing them again, holding their skirts demurely.

And if he had judged her harshly? If her life were a simple rosary of hours, her life simple and strange as a bird's life, gay in the morning, restless all day, tired at sundown? Her heart simple and wilful as a bird's heart? (Joyce 1968: 216).

The children who have stayed latest are getting on their things to go home for the party is over. This is the last tram. The lank brown horses know it and shake their bells to the clear night, in admonition. The conductor talks to the driver; both nod often in the green light of the lamp. There is nobody near[.] We seem to listen, I on the upper step and she on the lower. She comes up to my step many times and goes down again, between our phrases, and once or twice remains beside me, forgetting to go down, and then goes down. . . . Let be; let be..... And now she does not urge her vanities, - her fine dress and sash and long black stockings, - for now (wisdom of children) we seem to know that this end will please us better than any end we have laboured for (Joyce 1968: 268).

Clearly, one must be cautious not to expect too direct a correlation between the actual contents of Stephen's/Joyce's epiphanies and Malte's/Rilke's visions; the resemblance lies more in the atmospherics and the resonance of a given situation and the relevance, if not revelation, ascribed to a particular motif within its narrative context. Both Rilke 
and Joyce are providing a distinctive tonal perspective on a seemingly immaterial scene or object, lifting them out of their insignificance and bestowing on them a symbolical latitude that they otherwise lack. But while both Joyce and Rilke look at these epiphanies or visions as revelatory in nature, and while both are concerned with a "seeing" that is simultaneously an unveiling of the nature or essence of an event or a thing, they seem to present divergent models of how such a sudden spiritual experience comes about. In terms of sequencing, Joyce begins with the object or event which induces in the beholder a sudden manifestation of its "whatness." Rilke's Malte, by contrast, seems to be struck by the sudden spiritual manifestations as a consequence or extension of a pre-existing inner disposition: "Because you were a revealer, a timelessly tragic poet," Malte says, refering as much to Ibsen (as critics assume) $)^{15}$ as to his own creator,

you had to transform this capillary action all at once into the most convincing gestures, into the most available forms. So you began that unprecedented act of violence in your work, which, more and more impatiently, desperately, sought equivalents in the visible world for what you had seen inside. There was a rabbit there, an attic, a room where someone was pacing back and forth; there was a clatter of glass in a nearby bedroom, a fire outside the windows; there was the sun. [...] But this wasn't enough: finally towers had to come in and whole mountain-ranges; and the avalanches that bury landscapes spilled onto a stage overwhelmed with what is tangible, for the sake of what cannot be grasped (Rilke 1990: 83).

In his study of the epiphany, Morris Beja at one point notes, "this book [. . . ] attempts to show that, even if Joyce had never lived and Stephen had never roamed the streets of Dublin, what they both called "epiphany " would still have been a profoundly important presence in the contemporary novel" (Beja 1971: 14). Indeed, what could better corroborate this thesis than Rilke's poetry and his novel The Notebooks of Malte Laurids Brigge, created at the very moment when Joyce was conceiving and drafting his concept? The fact remains, however, that it was Joyce and not Rilke who provided literary scholars with this most convenient and suggestive of words to discursively link and classify the fascinating array of versions and adaptations of "a sudden spiritual manifestation" in twentieth-century literature, although in some ways not Joyce's Stephen Hero or A Portrait of the Artist as a Young Man, but rather Rilke's poetry might be said to constitute the ultimate epitome of the epiphany.

However we look at it, (re)reading Joyce against the background of Rilke and (re)reading Rilke against the backdrop of Joyce helps us not just to better understand the affinities between their works, but also to better define the major aesthetical and philosophical trends that characterized European modernism. It seems hardly coincidental that both of their life's stories and both of their life's work approximate more than any other modernist's œuvre what Georg Lukács has called the "transcendental homelessness" (transzendentale Obdachlosigkeit [Lukács 1977: 32]) of modernity and the modern novel. 
naterial scene $\mathrm{m}$ a symbollook at these arned with a an event or a itual experievent which 's Malte, by consequence aler, a timee) ${ }^{15}$ as to his

gestures ce in your the visiom where edroom, a lly towers andscapes cannot be

.] attempts l the streets profoundly what could oks of Malte ad drafting to provided liscursively den spiritnot Joyce's etry might :e and (re)sstand the 1 and philsincidental e than any homelessre modern

\section{Conclusion}

In conclusion, I hope to have shown that, despite the fact that we know of no direct factual link either between Rilke's and Joyce's lives or their œuvres, a comparative reading of their work can shed considerable light on the period and its intellectual heartbeat. Such less defined contact zones between writers surely must have as much a role to play in the future of reception studies as those more "pronounced" relationships - with direct links attestable through rapports de fait as is the case with Gustav Freytag and Heinrich Böll - that continue to form the staple of influence studies and comparative literary "normal science." And yet, and as we saw, even "causal" and seemingly unproblematical relationships like those between Gustav Freytag's Debit and Credit and Joyce's Ulysses or those between Joyce's works and Heinrich Böll's often produce rather unexpected interpretative difficulties. An "influence" is rarely as straightforward an analytical tool as one would hope.

So despite their traditional antagonism, most influence studies tend to revert to intertextual arguments about formal analogies, parallelisms, echoes, or traces as soon as they attempt to move beyond positivistic collation of facts and data to actual interpretative practice. Likewise, an intertextual interpretation will rarely convince without the substructure of influence - as for example evidenced in the recent work of Gérard Genette (1982), who subsumes under the term intertextuality much that would have qualified as influence in earlier comparative studies. The days are over when a Roland Barthes could pronounce with such unassailable conviction the incompatibility of influence and intertextuality:

The intertextual in which every text is held, it itself being the text-between of another text, is not to be confused with some origin of the text: to try to find the "sources", the "influences" of a work, is to fall in with the myth of filiation; the citations which go to make up a text are anonymous, untraceable, and yet already read: they are quotations without inverted commas (Barthes 1977: 160).

That is to say, the intertextual vistas opened up for interpreters by the study of less palpable and non-causal connections like those between Rilke and Joyce serve as useful counterparts to the interpretations produced by a more traditional approach premised on causal relationships. They are complements, not combatants. Indeed, much as the "Author" and authorial intention were proclaimed dead or defunct by theorists like Barthes or Michel Foucault in the mid-1960s and much as the "Author" - who was never really dead of course, just eclipsed by theory - staged a successful comeback in the 1990s, influence too was maybe too prematurely pronounced extinct (cf. Burke 1992 and Jannidis 1999). If we take a critical look back at the trajectories of both literary theory and literary critical practice over the past half-century we might note that, in many ways, the very practice of intertextuality itself now seems little more than an extension of the older paradigm of influence, complementing and refining rather than supplanting or usurping it. 
Notes

1 I use Shakespeare in Germany advisedly because, especially toward the end of the nineteenth century, Germans tended to regard Shakespeare as "their own" (unser Shakespeare). This was not least due to the many (excellent) translations of Shakespeare's works into German, among others by such seminal writers as Christoph Martin Wieland (1762) and August Wilhelm Schlegel and Ludwig Tieck (1797-1801 and $1825-33$ ), and the innumerable stagings of his plays throughout the century, not to mention the profound influence that Shakespeare's plays had on German writers. The prime example is, of course, Johann Wolfgang von Goethe's Wilhelm Meisters Lehrjabre of 1795 , cited in the "Scylla and Charybdis" chapter of Ulysses, the very chapter in which Stephen alludes to Shakespeare's domineering role in German turn-of-the-century intellectual life with the caustic remark "He [Shakespeare] was made in Germany ... as the champion French polisher of Italian scandals" ( $U$ 9 766).

2 Cf. most recently Saussy (2006) and Damrosch (2006).

3 Cf. Jean-Marie Carré, one of the leading scholars of the French School: "La littérature comparée est une branche de l'histoire littéraire: elle est l'étude des relations spirituelles internationales, des rapports de fait qui ont existés ...entre les œuvres, les inspirations, voire les vies d'écrivains appartenant à plusieurs littératures" (cited in Guyard 1951: 5).

4 Steinberg and Hallstein argue that all the German words Bloom uses are also Yiddish expressions; while this may be so, I am not convinced that Joyce would have been so sure about this. It seems more likely that for him, as for any reader of Ulysses who knows German, these words would ring German. However, I fully agree with their conclusion: "Taking this into account," they write, "there is no persuasive evidence in Ulysses to show that either Rudolph or Leopold Bloom knew (or did not know) German sufficiently well to read a novel such as Soll und Haben" (Steinberg and Hallstein: 546).

5 For more on this topic cf. also my (1995) survey of Arno Schmidt criticism, Framing a Novelist: Arno Schmidt Criticism 1970-1994.
6 "Ganz sicher ist - wären solche frivolen Bücher auch nur als potentielle Lektüre in ihre Nähe geraten -, sie wäre eher ein Proust- als eine Joyceleserin geworden" (Böll 1974: 64; my translation),

7 "Man schreibt ja nicht bewußt den Stil nach, praktisch wohl, sondern sucht seinen eigenen Ausdruck innerhalb der Spannungen des Autors, den man im Augenblick für vorbildlich hält. Der Vorgang ist interessant; aber ich glaube nicht, daß es irgend etwas über die Qualität eines Autors sagt, von wem er beeinflußt ist. Manchmal z.B. werde ich angeregt von einem blödsinnigen Film, den ich sehe, wo in irgendeiner Ecke eine Idee ist, die ich interessant finde und die vielleicht kitschig dargestellt ist. Das kann viel wichtiger sein, als Einstieg wichtiger werden, als die Gesamtlektüre von etwa Camus, der für mich interessant, sehr wichtig war" (Böll 1971: 7-8; my translation).

8 Born in Prague at a time when that city was one of the intellectual hubs of the Austro-Hungarian Empire, Rilke is "German" here of course exclusively in terms of language.

9 Rilke's text is cited from the translation by Stephen Mitchell (Rilke 1990).

10 "Ich möchte Dir sagen, liebe Lou, daß Paris eine ähnliche Erfahrung für mich war wie die Militärschule; wie damals ein großes banges Erstaunen mich ergriff, so griff mich jetzt wieder das Entsetzen an vor alledem was, wie in einer unsäglichen Verwirrung, Leben heißt" (Engelhardt 1974: 23; my translation).

11 "nicht plastische, geschriebene Dinge - Wirklichkeiten, die aus dem Handwerk hervorgehen"; quoted after Holthusen (1971: 86).

12 "statische, bildhaft beruhigte Situationen und Stimmungsbilder, in denen sich ein Stück gefühlter Welt, ohne Seufzer und Aufschrei, wie eine Sache präsentiert"; quoted after Holthusen (1971: 86).

13 It is worth pointing out that the relationship between Joyce, the epiphany, and Rilke that I highlight here is neither referenced nor discussed in Beja's excellent survey of the epiphany in the modern novel.

14 Pont du Carrousel:

$$
\text { arthes. R }
$$$$
\text { and trans }
$$$$
\text { Xang }
$$$$
\text { Bere } \mathrm{X} \text { ato }
$$$$
\text { ans the En }
$$$$
\text { Bex: Mortis }
$$$$
\text { Loodon }
$$$$
\text { Benstock. B }
$$$$
\text { drum or }
$$$$
\text { Jatses Jun }
$$$$
\text { Buoum. Hat }
$$$$
\text { York On }
$$ 
Der blinde Mann, der auf der Brücke steht, grau wie ein Markstein namenloser Reiche, er ist vielleicht das Ding, das immer gleiche, um das von fern die Sternenstunde geht, und der Gestirne stiller Mittelpunkt. Denn alles um ihn irrt und rinnt und prunkt.
Er ist der unbewegliche Gerechte, in viele wirre Wege hingestellt; der dunkle Eingang in die Unterwelt bei einem oberflächlichen Geschlechte. (Rilke 1948: 119)

15 Cp. Manfred Engel's commentary (Rilke 1997: 260).
Stil nach, $n$ eigenen ngen des $r$ vorbildsant; aber s über die $m$ er beeangeregt ich sehe, t, die ich kitschig iger sein, die Gesamich in71: 7-8; y was one -Hungarof course

lation by

Aaß Paris $r$ wie die $s$ banges ich jetzt was, wie 'n heißt'

- Wirkervorge$6)$. nen und tück gearei, wie olthusen tionship Ike that nor disepiph-

\section{BIBLIOGRAPHY}

Barthes, Roland (1977) Image - Music - Text, sel. and trans. Stephen Heath. New York: Hill and Wang.

Bate, Walter Jackson (1971) The Burden of the Past and the English Poet. London: Chatto and Windus.

Beja, Morris (1971) Epiphan in the Modern Notel. London: Peter Owen.

Benstock, Bernard (1976) "The Kenner conundrum: or who does what with which to whom." James Joyce Quarterly 13:428-35.

Bloom, Harold (1973) Anxiet) of Influene. New York: Oxford University Press.

Böll, Heinrich (1971) Im Gespräch: Heinrich Bäll mit Heinz Ludwig Amold. Munich: Richard Boorberg Verlag.

Böll, Heinrich (1974) Gruppenbild mit Dame. Cologne: Kiepenheuer und Witsch.

Böll, Heinrich (1977) "'Ich habe nichts über den Krieg aufgeschrieben. 'Ein Gespräch mit Heinrich Böll und Hermann Lenz." In Nicolas Born and Jürgen Manthey (eds.) Literaturmagazin 7. pp. 30-74. Reinbek: Rowohlt.

Burke, Sean (1992) The Death and Retum of the Author: Criticism and Subjectivity in Bartbes. Foucault and Derrida. Edinburgh: Edinburgh University Press.

Damrosch, David (2006) "Rebirth of a discipline: the global origins of comparative studies," Comparative Critical Studies 3:99-112

Eliot, T. S. (1975 [1923]) "Ulysses, order, and myth." In Frank Kermode (ed.) Selected Prose of T. S. Eliot, pp. 175-8. New York: Harcourt Brace Jovanovich

Engelhardt, Hartmut (ed.) (1974) Materialien zu Rainer Maria Rilkes "Die Aufzeichnungen des Malte Laurids Brigge, "Frankfurt: Suhrkamp.

Freytag, Gustav, with a Preface by Chevalier Bunsen (1858) Dehit and Credit. New York: Harper.

Genette, Gérard (1982) Palimpsestes: La littérature au second degré. Paris: Éditions du Seuil.

Guillén, Claudio (1971) Literature as System: Essays touard the Theory of Literam History. Princeton, NJ: Princeton University Press.

Guyard, Marius-François (1951) La Littérature comparée. Paris: Presses Universitaires de France.

Holthusen, Hans Egon (1971) Rilke. Reinbek: Rowohlt.

Jannidis, Foris (ed.) (1999) Rückkehr des Autors. Zur Emekerung eines umstrittenen Begriffs. Tübingen: Niemeyer.

Joyce, James (1968) A Portrait of the Artist as a Young Man: Text. Criticism. and Notes, ed. Chesrer G. Anderson. New York: Viking Press.

Lukács. Georg (1977) Die Theorie des Romans. Ein geschichtspbilosophischer Versuch über die Formen der graßen Epik. Darmstadt and Neuwied: Luchterhand.

Mitchell, Breon (1976) James Joyie and the German Nowel 1922-1933. Athens, OH: Ohio University Press.

Rilke, Rainer Maria (1939) Poems, trans. J. B. Leishman. London: Hogarth Press.

Rilke, Rainer Maria (1948) Ausgewäblte Werke, Vol. 1: Gedichte. Frankfurt: Insel.

Rilke, Rainer Maria (1990) The Notebooks of Malte Laurids Brigge, trans. Stephen Mitchell. New York: Random House (Vintage)

Rilke, Rainer Maria (1997) Die Aufzeichnengen des Malte Laurids Brigge. Kommentierte Ausgabe, ed and commentary by Manfred Engel. Stuttgart: Reclam.

Saussy, Haun (2006) "Exquisite cadavers stitched from fresh nightmares: of memes, hives, and selfish genes." In Haun Saussy (ed.) Comparative Literature in an Age of Globalization, pp. 3-42. Baltimore, MD: The Johns Hopkins University Press

Steinberg, Erwin and Christian Hallstein (2003) "Probing silences in Joyce's Ulysses and the question of authorial intention." James Joyce Quarterl, 40: 543-54. 
Weninger, Robert (1995) Framing a Novelist: Arno Schmidt Criticism 1970-1994. Columbia, SC: Camden House.

Weninger, Robert (1998) "Böll and Joyce, Joyce on Böll: a gnomonic reading of Heinrich Böll's Irish Journal." In Joachim Fischer, Gisela Holfter, and Eoin Bourke (eds.) Deutsch-Irische Verbindungen. Geschichte-Literatur-Übersetzung, pp. 133-43. Trier: Wissenschaftlicher Verlag.
Weninger, Robert (2004) "James Joyce in Germanspeaking countries: the early reception 1919 1945 " and "The institutionalization of 'Joyce'. James Joyce in (West) Germany, Austria and Switzerland 1945 to the present." In Geert Lernout and Wim van Mierlo (eds.) The Reception of James Joyce in Europe, pp. 14-69. London: Continuum.

$$
\begin{aligned}
& \text { A nes } \\
& \text { uscal } \\
& \text { wirb } \\
& \text { herme } \\
& \text { whact } \\
& \text { of the } \\
& \text { ane ma } \\
& \text { Ir is. } \\
& \text { and } \\
& \text { and } t \\
& \text { adign }
\end{aligned}
$$

\section{Moll}

